\title{
Integrative Liberal Learning: A Case for Internships and Other High Impact Practices as an Essential Component in Students Professional Preparation
}

\author{
Lorelei A. Ortiz \\ St. Edward's University \\ Catherine MacDermott \\ St. Edward's University
}

High impact practices that promote experiential learning and develop competencies to facilitate job readiness upon graduation have become essential to the student experience. From an integrative learning framework, this article examines four years of results from employer feedback evaluations for business interns enrolled in a Business Internship course. This cross-section of exit data illustrates three important factors: 1) the skills students apply and develop during internships, 2) the intern competencies desired and expected by employers, and 3) the level of success interns achieve when it comes to meeting employer demands and expectations in organizational roles. The article concludes with implications for business curriculum and career planning and preparation practices.

\section{INTRODUCTION}

A liberal arts education is often associated with carefully designed programs that are intentional in their efforts to guarantee student success throughout their four years of undergraduate study and beyond (Ferren \& Anderson, 2016). Traditionally, three broad-based goals of a liberal education are often cited by students and their parents as reasons for choosing such an educational opportunity, regardless of major chosen - big picture knowledge about the wider world, well-developed powers of the mind, and examined commitments to ethical and social responsibility. However, as the cost of education continues to rise, students and parents have begun to question the relevance of a liberal education and a university's ability to help prepare graduates for the career demands of a rapidly changing, global economy (Calder \& Steffes, 2016; Kao \& Mao, 2015).

For business majors in particular, the question of employability and return on investment for a liberal arts education is a key focus of their academic experience. High impact practices such as internships, that promote experiential learning, are staples in AACSB-accredited business schools and guide much of the curricular and co-curricular student experience, with the end-goal of developing competencies that will facilitate employment and job readiness upon graduation. This raises curiosity as to how students are engaging with these experiences, how successfully they are applying and developing professional skills, and how employers are assessing student success in relation to career readiness. In response to these questions and within the context of integrative learning practices, this article highlights four years of results from employer feedback evaluations for business interns enrolled in a junior-to-senior level 
Business Internship course from 2011 to 2014 . This cross-section of exit data is valuable as an illustration of three important factors: 1) the skill sets students apply and develop during internships, 2) the intern competencies desired and expected by employers, and 3) the level of success interns from business majors are achieving when it comes to meeting employer demands and expectations in organizational roles. The article concludes with best practices grounded in integrative liberal learning, both curricular and cocurricular, as well as implications for business curriculum and practices for career planning and preparation, particularly in liberal arts institutions.

\section{Literature Review}

In the last decade employers have expressed frustration about the lack of job readiness skills of new hires, predominantly in areas of critical thinking, problem solving, well-developed communication skills, team and leadership skills, professionalism and workplace savvy (Minton-Eversole, 2012; Apparaju, 2016; Ortiz et al, 2016; MacDermott \& Ortiz, 2017). The universal skills employers seek require high levels of emotional/social intelligence and the four C's of critical thinking, communication, collaboration, and creativity (Cialdini, 2012; AMA, 2010). According to Gregg and Stewart (2013), employers expect talented professionals who are ready to execute with little or no on-boarding (plug ' $n$ play), a measurable set of skills that add value to process efficiency and specific identifiable competencies . . . able to think, plan and act independently, solve problems with the big picture in mind and communicate across functional sub-cultures" (p. 17). These shifting requirements of work have serious implications for how universities help students prepare for their life after college; and, perhaps more importantly, how universities help students become more adaptive and able to possess and articulate the transferable skills that are essential to career success.

One of the ways universities have been preparing students to develop transferable skills and gain valuable experience sought after by hiring managers is through credit-bearing internships where a faculty member guides the learning process, helping the student document, articulate, and reflect on his/her learning and enhanced skill development. Prior to the $1990 \mathrm{~s}$, formal, credit-bearing internships were not common. As a matter of fact, internships, whether they were credit-bearing or not, were not common. From the mid 1980 s to the mid 2000 s, the share of college graduates engaging in a minimum of at least one internship prior to graduation rose from less than $10 \%$ to over $80 \%$ (Cook et al., 2004).

Increasingly, interns have reported that the high-impact practice of guided internships has resulted in higher starting salaries (Gault et al., 2000); greater job satisfaction (Gault et al., 2000; Knouse \& Fontenot, 2008; MacDermott, 2017); more job offers (Gault et al., 2000; Knouse \& Fontenot, 2008; Divine et al., 2007; D'Abate et al., 2009); soft skill development (Knemeyer \& Murphy, 2002; MacDermott 2017); and better career and job-related preparation (Gault et al., 2000; Divine et al., 2007; MacDermott, 2017). Intern supervisors are also finding strategic internship programs helpful as the 3-plus month internship allows employers to proactively identify, attract, and access talent. The internship period allows both the organization and the intern an extended period to assess fit for the organization (Smith, 2014; Gault et al., 2010). A 2012 Chronicle of Higher Education and American Public Media's Marketplace survey of employers who hired recent college graduates attempted to understand employer perceptions of the role of colleges and universities in career preparation. Of the employers surveyed, internships were identified as the single most important credential for recent college graduates to have on their resume (Thompson, 2014), further pointing to the positive outcome of internships.

\section{Historical Perspective}

The framework for career management skills development has slowly evolved since the early 1980 s when National Career Development Guidelines were introduced (Jarvis \& Kelley, 2003). Hooley et al. (2013) point out that since that time, the guidelines have been revised in 2004 and 2007 to comprise three core areas. The first core area is identified as career learning, which includes (a) personal management, (b) education and life-long learning, and (c) career management. The second core area is framed around learning models, with the existing iterations derived from Bloom's taxonomy, whereby career skills are acquired through knowledge, application, and reflection. The third core element of the framework is the 
notion of learning levels, which addresses when career skills should be learned. In essence, this evolving model has addressed the questions of (1) what career management skills should be learned, (2) how they should be learned, and (3) when they should be learned. However, the question that is not answered is where should these career skills be learned? This is where an integrative liberal learning approach that includes high impact practices could address the context of learning career management skills through curricular, co-curricular and workplace settings.

\section{Integrative Liberal Learning Practices}

As a result of the fluctuating work demands and the need for higher education to adapt, colleges and universities are rethinking the delivery of a liberal arts education and adopting new programs to better prepare graduates for a changing and competitive economy. One of the challenges facing higher education is helping students integrate their learning. The ability to make connections and articulate the transfer of knowledge and acquired skills in diverse settings is critical for personal and professional life beyond college campuses and is at the heart of liberal arts education.

Huber and Hutchings (2004) argue that many of the existing academic frameworks discourage integration, but rather encourage students to see college experiences as stand-alone silos, with little, if any, integration. The AAC\&U Integrative Learning Monograph (2007) posits that "the undergraduate experience can be a fragmented landscape of general education courses, preparation for the discipline, cocurricular activities, and the "real world' beyond the campus." However, research tells us that an emphasis on integrative liberal learning can help undergraduates put the pieces together and develop habits that prepare them to make informed decisions in the context of their personal and professional lives (Bartley \& Robitschek, 2000; Bridgstock, 2009; Brown, 2004; Davey, 2010; Pool et al., 2013; \& Portfeli \& Skorikov, 2010). Supporting this notion, Rover (2007) suggests that integrative learning comes from connecting skills and knowledge from various experiences, both in an out of the classroom. Knowledge within a student's major is the foundation for discipline-specific wisdom; however, integrative learning is central to personal and professional success (Huber \& Hutchings, 2004). Integrative liberal learning practices feature increased attention to career preparation through more intentional career exploration, professional network development and mentoring, and program designs that recognize the stages of student development and the importance of scaffolding experiences throughout the four-year undergraduate experience (Ferren \& Paris, 2015; Rudgers \& Peterson, 2017).

Integrative liberal learning is a necessity for the rapidly changing and global interconnected world facing our graduates. Students often experience a good deal of apprehension about post college career decisions (Skorupa \& Agrest, 1998); however, utilizing an integrative liberal learning model that includes assisting students in the career search process through self exploration, preparation, and experience can help demystify the career management process and make it more compelling for students to engage in this decision-making process in a thoughtful, intentional way.

Drawing from these findings, developing an intentional career program that utilizes early and frequent career guidance, preparation and high impact experience will increase occupational engagement and self and world knowledge as it relates to meaningful, professional lives. The goal, then, is to engage students in an intentional program of career exploration, preparation and experience to support the evolution of their professional lives.

\section{Career Planning and Preparation}

To ensure that an integrative liberal learning model is grounded in career management principles, it is necessary to look to research to understand key concepts that guide student learning outcomes. Bridgstock (2009) argues that graduates must be able to proactively self-manage the career building or career management process, beginning with career exploration, followed by preparation and experience. Career exploration involves activities that attempt to illuminate knowledge of oneself, such that the self

discovery prompts reflection and a better understanding of one's personality traits and how they might fit into the world of work (Atkinson \& Patricia, 1988; Barrick et al., 2013; Bluestein \& Flum, 1999; Stumpf, et. Al., 1983, 1984; Levi \& Ziegler, 1993; Porfeli \& Skorikov, 2010). 
Further, Keishing \& Renukadevi (2016) found that students who participated in career planning and preparation programs in their early years of undergraduate study were significantly more active in career planning efforts and reported greater confidence in their ability to make career decisions. Combined with career planning and preparation programs, research has shown that having a wide range of experiences helps influence career decision-making processes (Brown, 2004). These experiences ranged from in class and out of class, on campus or off campus and from formal (e.g. class work, internships, research) to informal experiences (e.g. student government, clubs, organizations, athletics, community service, and study abroad). Based on the "Wisdom Model" developed by Brown (2004), "experiences were characterized by the extent to which those experiences provided new perspective, facilitated a new discovery of self and/or interests, promoted self-reflection and provided the opportunity to apply skills and knowledge."

According to the Gallup-Purdue study (2015), "the value of a college education is being more determined by meaningful experiential learning opportunities that have a lasting impact on graduates' lives." Experience, alone however, is not enough. It is what one does with these experiences that is transformational. Carol Rodger's (2002) research and analysis of John Dewey's body of research on reflection posits that reflection is an intentional tool that can be used as a transformational, meaningmaking experience. Reflection is grounded in the scientific method and has precise steps that can be assessed and measured (Dewey, 1933). Rodgers (2002), argued that "the creation of meaning out of experience is at the very heart of what it means to be human," and by extension, it is at the very heart of a liberal arts education, regardless of the major chosen.

For business majors, reflection is a key component of learning across the business curriculum and cocurriculum. Lessons learned projects, case and simulation analyses, reflections on successes and failures, intentional networking activities, and internships, for example, are all part of the natural processes of learning for business. And because the business internship course centers on organizational problem solving and what the intern is contributing and learning in the workplace, this type of course provides a perfect environment for self-reflection and transformation while at the same time creating opportunities for students to develop essential professional skills.

\section{The Business Internship Course}

Business Internship courses across universities and colleges are likely to share certain characteristics and learning objectives, with the end goal of preparing students for success in the workplace. The Business Internship course featured in this article is housed in the business school of a small, liberal arts university in Austin, Texas. The course is a junior to senior level 3-credit course that is highly experiential and reflective and counts as an upper-level business elective in the students' major (business administration, management, finance, economics, accounting, entrepreneurship, international business, marketing, and digital media management). Students in all majors across the business school are required to take 3 upper level business electives and the internship course can count as one of those courses. They may take the internship course more than once as long as the internship is different from the previous time they were enrolled in the course. Students in the Business Internship course must complete a minimum of 120 hours of internship work during the term and the work they do must be related to their major/discipline. Internship sites for students vary given the richness of industry in Austin, Texas, the state's capital. These sites typically include marketing firms, state and local government agencies, consulates, entertainment venues and festivals, technology and telecommunications companies, financial institutions, business startups, and non-profit organizations, to name a few. The Business Internship course requires four major assignments and some administrative activities to document the place of internship and the type of work they will do, as illustrated in Table 1. 
TABLE 1

BUSINESS INTERNSHIP ASSIGNMENTS AND ACTIVITIES

\begin{tabular}{|l|l|}
\hline ASSIGNMENT & POINT VALUE \\
\hline $\begin{array}{l}\text { - Students submit Internship information and supervisor name } \\
\text { and contact information using Box via Canvas learning } \\
\text { management system } \\
\text { - Students also submit internship job description in Canvas }\end{array}$ & $\begin{array}{l}\text { No point value assigned but } \\
\text { students are administratively } \\
\text { withdrawn from the course if } \\
\text { they do not submit these by the } \\
\text { deadline (usually two weeks } \\
\text { after the start of the semester) }\end{array}$ \\
\hline $\begin{array}{l}\text { Reflective Paper 1: Goal Setting, Career Path, and Internship- } \\
\text { Researching career path and identifying actionable goals }\end{array}$ & 100 points \\
\hline $\begin{array}{l}\text { Midterm Internship Log-Documentation of what students are } \\
\text { learning, how they are applying it, what they have contributed to } \\
\text { the organization }\end{array}$ & 100 points \\
\hline $\begin{array}{l}\text { Reflective Paper 2: Self-Assessment-Takeaways and learning } \\
\text { from the internship }\end{array}$ & 100 points \\
\hline $\begin{array}{l}\text { LinkedIn Profile Update-Students use content from deliverables } \\
\text { above to update their online profiles }\end{array}$ & 100 points \\
\hline Total Possible Points: & 400 \\
\hline
\end{tabular}

At the end of the term, the course instructor distributes an online Qualtrics survey to employers in order to solicit feedback on intern performance. Two sections of this course are typically offered during each semester, taught by two different instructors, with student load limits of 15 per section.

\section{The Online Employer Evaluation Survey}

The online employer evaluation Qualtrics survey was distributed at the end of both spring and fall terms between 2011 and 2014. In total, 160 responses were recorded from internship supervisors during this period. The evaluation feedback survey included nine questions: one sliding scale question about intern performance related to 17 skill areas and an assessment of overall performance; one question about whether the employer would recommend the intern for another internship or job; three questions asking for open-ended comments; three questions related to the employer's perception of the internship program; and a final question asking if the employer would be willing to accept another intern in the future (see survey in Appendix A).

\section{Results}

Results of the employer feedback survey show that, overall, students performed well in their internships, with 143 out of the 160 employers who responded willing to recommend the intern without hesitation. Ten would recommend with reservations, and only two would not recommend the intern for another internship or job. 


\section{FIGURE 1 \\ EMPLOYERS WOULD RECOMMEND THE STUDENT FOR \\ ANOTHER INTERNSHIP OR JOB}

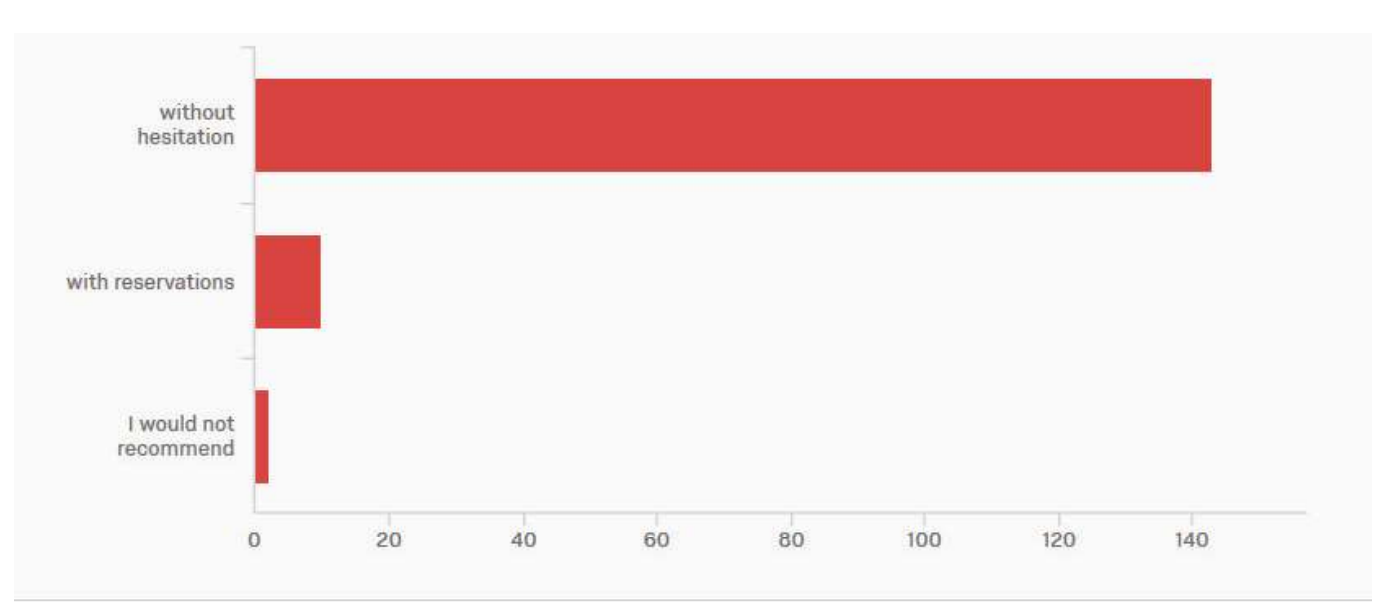

Of the 160 employers who responded, 128 of those who would recommend without hesitation would also be willing to accept another intern, while only 12 would not.

FIGURE 2

\section{THOSE WHO WOULD RECOMMEND AND WOULD BE WILLING TO ACCEPT ANOTHER INTERN}

\begin{tabular}{|l|l|c|c|c|c|}
\cline { 3 - 6 } \multicolumn{2}{c|}{} & \multicolumn{3}{|c|}{ I would recommend this student for another internship or job. } \\
\cline { 3 - 6 } & \multicolumn{2}{|c|}{ without hesitation } & with reservations & I would not recommend & Total \\
\hline \multirow{2}{*}{ Would you be willing to accept another intern? } & Yes & 128 & 8 & 2 & 138 \\
\cline { 3 - 7 } & No & 12 & 2 & 0 & 14 \\
\hline
\end{tabular}

Of the 143 employers who would recommend without hesitation, 133 ranked the interns overall performance at a mean score of 96.04 out of 100 with a standard deviation of 9.43 . Of the 10 employers who would recommend with reservations, the mean score assigned to interns overall performance was 77.50 out of 100 with a standard deviation of 5.64. Of the two who would not recommend, one employer ranked the intern's overall performance at 39.00 out of 100 with a standard deviation of 0 since it was the only response submitted of the two who would not recommend. The full range of scores is summarized in Appendix B.

In regards to field 16, "Other areas of performance specific to this internship," employer responses ranged broadly and included skills such as financial analysis, team skills, personal confidence, research skills, maturity, positive attitude, detail-oriented, persuasiveness, demeanor and professionalism, enthusiasm, professional attire, creativity, initiative and self-motivation.

Employers' open-ended comments provide additional context for intern performance in key areas and include strengths and opportunities for development, as seen in Tables 2 and 3. 
TABLE 2

EMPLOYER OPEN-ENDED FEEDBACK: AREAS OF STRENGTH

\author{
Supervisor Open-Ended Feedback: Areas of Strength
}

Chase did an outstanding job as our intern this summer. He took on a project most people would find tedious and boring. However, Chase embraced his charge, jumped right in, and knocked it out. This was a large data project he tackled. So large we initially thought it would require two interns. Chase was so hard working and efficient, he actually completed it early and was able to assist my team with some other pressing projects.

Kim has been a great member of our team here. I'm looking forward to having her grow with our company.

Rob has been awesome. He's quickly caught on to anything we've asked him to do, and then proposes ideas for how to do more without waiting for us to come to him. He seems to be learning a lot and has made valuable contributions to the team.

Holden has been a great addition to our team and took over a lot of the responsibilities that I originally did in the past. He's been attentive, organized, and has shown his creativity in finding different strategies to implement into our sales funnel. We feel so strongly about his progress that we've offered him a full-time internship so that he can become further involved in our day-to-day operations.

Andrea did an outstanding job on all tasks assigned and even tasks not assigned but she identified needed attention.

Lily was great, super-responsive, very eager to work and a fast learner.

Mike has been a KEY person to our establishment this season! Everyone has enjoyed his work ethic and attitude around the office and out of the office! Mike has shown a great interest in this company.

We can always count on him to be on time, and perform the best he can in our work environment.

Overall, employers' positive feedback cites strengths such as efficiency, initiative, attentiveness, organization, positive attitude, and work ethic.

Areas for improvement identified by employers include dependability and timeliness, immaturity/lack of professionalism, and ability to take direction, as illustrated in Table 3. 
TABLE 3

\section{EMPLOYER OPEN-ENDED FEEDBACK: AREAS FOR IMPROVEMENT}

\begin{tabular}{|c|}
\hline Employer Open-Ended Feedback: Areas for Improvement \\
\hline $\begin{array}{l}\text { John was a good employee when he was performing a task her was interested in. He had difficulty } \\
\text { taking supervision and showed an immature side. With his direct manager, he would refuse to answer } \\
\text { emails or speak or speak with a clipped tone if he were upset with her. John will make a good } \\
\text { employee when he finds a position that is what he is interested in and learns to take direction. He was } \\
\text { not able to make the transition from intern to part time position as an employee. }\end{array}$ \\
\hline $\begin{array}{l}\text { David is a very personable young man with good intentions. He needs to learn better organizational, } \\
\text { planning, and time management skills so that he can be better at making deadlines and managing tasks. } \\
\text { He consistently had trouble making it to work on time for various and most often avoidable reasons. } \\
\text { David has a tendency to make the same avoidable mistakes over and over - whether it's formatting a } \\
\text { document, completing a spreadsheet, or selecting the correct email address for a contact. Task } \\
\text { checklists were provided and reviewed with David at the outset of his internship but he didn't appear to } \\
\text { use these tools. He was provided contacts to help him with his work and he had trouble leveraging } \\
\text { these resources. He has difficulty completing work when he is not in the office. To earn an A for this } \\
\text { internship David would need to demonstrate excellence in all areas, invested in the effort needed to } \\
\text { "get things done" solve problems, and would have achieved the agreed upon targets and tasks. David is } \\
\text { at best a C performer. I would expect C performers to at least show up to work as scheduled and not } \\
\text { continue to make the same mistakes again and again two areas that seem difficult for David. }\end{array}$ \\
\hline $\begin{array}{l}\text { Rae started off the semester very strong. Her work showed thought, interest, and skill in grassroots } \\
\text { marketing campaigns both online and offline. She contributed to the marketing campaigns of artists and } \\
\text { showed dedication to the internship program and even attended our event in NYC where we had label } \\
\text { presentations and in-office performances for our interns. I have one reservation about her performance; } \\
\text { as the internship progressed, Rae missed some deadlines. We understand that the end of the semester } \\
\text { can be very busy for students, but expect that they carry through with their commitment. Aside from } \\
\text { this, Rae did excellent work for us and was an asset to the team. When she was here she worked well. } \\
\text { However, her last day with us was on } 11 / 19 \text {. I received an email on } 11 / 20 \text { letting me know she would } \\
\text { not be returning citing personal reasons. }\end{array}$ \\
\hline
\end{tabular}

Tom does great work when he is available. The trouble we had with Tom was reliably knowing when he would be available. There was always a reason why Tom was late or didn't show up at all, and he did a reasonable job of communicating when something was going to prevent him from coming in as scheduled. However, I think Tom can do a better job with his reliability. Tom needs to learn how to set things aside that might be distracting him or just plan his time better and get to work. I think internships are a great low risk way to learn about the work world. So, my hope is that Tom takes this feedback constructively, and learns how to manage his time in way that he can be a reliable resource. If he doesn't, he'll struggle when he gets a full-time position.

Unfortunately, Brian seemed to have one excuse after another for why he could not come to work or would need to reschedule/delay his work hours. He seemed to take advantage of our flexible nature and the fact that his supervisors were frequently out of the office due to the nature of our business. In the few months he has worked with us he has given more excuses for why he could not stick to the predetermined schedule than either of our two other employees in the 4 years they have been with us. His work product was less than impressive but good enough to meet requirements.

Harlan was an eager employee, but often while trying to be gregarious and friendly with the staff, he would act unprofessionally. Our office is laid back and while these actions aren't that distracting, they could potentially affect him in the future in a professional business setting. 


\section{DISCUSSION}

Results of the employer feedback survey suggest that interns are, in most cases, capable of meeting most employer expectations, as evidenced by 143 of the 160 employer respondents' willingness to recommend the intern for another internship or job without hesitation (89\%) and 128 of those respondents (80\%) also willing to accept another intern. For the 12 employers who would not be willing to accept another intern, there is no data to explain if that decision is based on the performance of the intern, budgetary constraints, or lack of organizational need. Intern success may also be measured by summative performance scores where the majority of employers who would recommend the intern without hesitation, 133 out of the 160, assigned a mean score of 96.04 to the intern's overall performance (standard deviation 9.72). Employers further contextualize the survey results by providing open-ended feedback that reflects positive workplace behaviors exhibited by interns such as efficiency, initiative, attentiveness, organization, constructive attitude, and strong work ethic.

Feedback results also underscore there is still work to be done, particularly as it relates to interns' dependability, punctuality, and sense of professionalism. The 10 employers who would recommend with reservations assigned mean scores of 59.30 for intern punctuality and 70.20 for dependability. The two employers who would not recommend the intern assigned mean scores of 69.50 for punctuality and 58.50 for dependability. Employer open-ended feedback supports the notion that interns need additional education, skills development, and self-reflection focused on these workplace behaviors as well as in decorum and professionalism.

Best practices in integrative liberal learning, both curricular and co-curricular, can play an important role in enhancing the development of key professional and life skills such as those highlighted in the employer feedback survey. High impact curriculum and supporting co-curricular activities and university practices for career planning and preparation are essential. Universities and colleges must create strong coordination and engagement connections with career and professional development offices on campus to facilitate intentional opportunities for students to learn, apply, and reflect on their trajectory for career success and to development identifiable, realistic, and actionable goals as part of career preparation and planning. Equally valuable are opportunities for students to exercise professional and life skills in-situ through high impact activities such as internships, field experiences, study abroad, and networking events. Curricular support that engages the student in reflective and deliberative analysis helps them to more clearly understand their goals and to take intentional steps towards their professional vocation.

Moreover, curricular support can include developing experiential links between faculty and campus resources in order to bring the support to the classroom, tying course activities to engagement opportunities across campus such as guest speakers, faculty led study abroad programs, service learning opportunities, career and internship fairs, and one-on-one consultations with career counselors. In essence, as Ferren and Paris (2015) argue, integrative liberal learning "articulates a set of principles and practices that reflect a more holistic concept of undergraduate education that focuses on student empowerment and self-development; intentionally integrated learning opportunities and experiences; and greater clarity and transparency of learning outcomes for students, faculty, and other stakeholders."

The value of integrative, high impact learning can be appraised in the statistics below which provide some interesting data points about experiential education. These statistics are from the liberal arts university and the business school that house the Business Internship course featured in this article: 


\begin{tabular}{|c|c|c|}
\hline Type of Experiential Education Completed & $\begin{array}{c}\text { All Traditional } \\
\text { Undergraduates }\end{array}$ & Business Majors \\
\hline Internship & $74.8 \%$ & $72.9 \%$ \\
\hline Assistantship & $25.6 \%$ & $10.1 \%$ \\
\hline Field Experience/Practicum & $18.6 \%$ & $7.8 \%$ \\
\hline Clinical Experience & $6.8 \%$ & $0.0 \%$ \\
\hline Service Learning & $27.9 \%$ & $18.6 \%$ \\
\hline Completed some type of experiential education prior to graduation & $88.3 \%$ & $82.2 \%$ \\
\hline Of those completing internships: & $\begin{array}{l}\text { All Traditional } \\
\text { Undergraduates }\end{array}$ & Business Majors \\
\hline - completed more than 1 internship & $48.5 \%$ & $54.3 \%$ \\
\hline - completed more than 2 internships & $18.9 \%$ & $14.9 \%$ \\
\hline - completed more than 3 internships & $5.8 \%$ & $5.3 \%$ \\
\hline - completed more than 4 internships & $1.4 \%$ & $2.1 \%$ \\
\hline - received pay for an internship & $50.1 \%$ & $74.5 \%$ \\
\hline - received credit for an internship & $66.3 \%$ & $50.0 \%$ \\
\hline $\begin{array}{l}\text { - received offer for full-time employment as a result of } \\
\text { internship } \\
\text { - reported internship was helpful/very helpful in preparing }\end{array}$ & $20.5 \%$ & $28.7 \%$ \\
\hline for workforce & $89.3 \%$ & $92.6 \%$ \\
\hline Response Rate & $65.0 \%$ & $64.2 \%$ \\
\hline
\end{tabular}

Source: Survey for the Class of 2016 (December 2015, May 2016, and August 2016)

The above numbers show that, university-wide, $88.3 \%$ of students in the class of 2016 completed some type of experiential education before graduation and $89 \%$ university-wide (and $93 \%$ of business majors) reported that doing an internship was helpful/very helpful in preparing for the workplace. Thus, student preparation through integrative experiential practices can be highly relevant and valuable to student development and success. It is equally important in terms of the quality of graduates that universities and business schools produce. As Kao \& Mao (2011) argue, "viewing internships from the perspective of student competitiveness can provide a conceptual and practical framework for business schools to identify relevant change drivers, design flexible curricula, and enhance their graduates' competitiveness in global markets. Such curriculum can integrate co-curricular resources available to students as part of the academic environment" (p.10). And, as one employer noted in his feedback survey, "internships are a great low risk way to learn about the work world" so there is much for students to gain and little to lose when they engage in high impact, experiential activities such as internships.

DePillis \& Johnson (2015) underscore the added consideration of outcomes assessment which must be important to every school, particularly business schools that are AACSB accredited where assessment is key to the accreditation cycle. As DePillis \& Johnson point out, "universities are expected to define what we are trying to teach, measure how well our students are learning these things, and 'close the loop' by going back and adjusting curriculum to address any weaknesses. Presumably, measurable improvements in learning and student success will follow, completing a cycle in the continuous improvement model" ( $p$ 58). Clearly, integrated liberal learning activities can become a useful tool for assessment, in addition to the many benefits and advantages it provides for students.

\section{LIMITATIONS}

This article illuminates a subset of data that is part of a larger argument for integrative liberal learning that engages experiential, high impact curriculum and co-curriculum. The employer feedback data is valuable for understanding how employers prioritize intern skills and what skill sets, aside from the 
standard soft skills, they expect interns and new hires to possess upon entry into the workforce. The limitation of this data is that, while it covers a substantial cross-section of data during a four year time period, it does not extend past 2014. A recent restructuring of the Business Internship course to accommodate more students per section and a revised employer feedback survey will be implemented next year to continue to gather valuable feedback from employers.

\section{CONCLUSION}

Current college graduates require adaptive capacities and transferable skills in order to meet the demands of employers and thrive in a rapidly changing economic landscape. A rich and multidimensional education that includes experiential and integrative learning can provide students with the broad perspective, critical thinking, creative problem-solving, and well-developed communication skills that will serve them well in their careers. Through an integrative liberal learning practices, students can learn to recognize and articulate how their education is preparing them professionally. When carried out deliberately and with purpose, liberal learning, high-impact practices can further students' understanding of themselves and their sense of purpose in relation to their work and the broader community.

\section{REFERENCES}

American Management Association 2010 Critical Skill Survey. (April 15, 2010). Retrieved from http://www.amanet.org/news/ama-2010-critical-skills-survey.aspx

Apparaju, H. (2016). How effective are the persuasive and other communication abilities of MBA students in India: Implications for business communication courses. The IUP Journal of Soft Skills, 10(3), 24-37.

Atkinson, G., \& Murrell, P. (1988) Kolb's experiential learning theory: A meta-model for career exploration. Journal of Counseling \& Development, 66(8), 374-377.

Barrick, M., Mount, M., \& Li, N. (2013). The theory of purposeful work behavior: the role of personality, higher-order goals, and job characteristics. Academy of Management Review, 38(1), 132-153.

Bartley, D., \& Robitschek, C. (2000). Career exploration: a multivariate analysis of predictors. Journal of Vocational Behavior, 56(1), 63-81.

Bluestein, D., \& Flum, H. (1999). A self-determinant perspective of interest and exploration in career development. In M.L. Savicksas, \& A.R. Spokane (Eds.) Vocation interests: meaning, measurement, and counseling use, 345-368.

Bridgstock, R. (2009). The graduates attributes we've overlooked: enhancing graduate employability through career management skills. Higher Education Research \& Development, 28(1), 31-44.

Brown, S. (2004). Where this path may lead: understanding career decision-making for postcollege life. Journal of College Student Development, 45(4), 375-390.

Calder, L., \& Steffes, T. (2016). Measuring college learning in history. Measuring college learning, Social Science Research Council, 37-86.

Cialdini, R.B. (2012). Influence: The art of persuasion. London, England: Profile Books LTD.

Cook, S.J., Parker, R.S., \& Pettijohn, S.E. (2004). The perceptions of interns: A longitudinal case study. Journal of Education for Business, 79, 179-185.

Cox, D., Bjornsen, A., Krieshok, T., \& Lui, Y. (2016). Occupational engagement and academic major satisfaction: Vocational identity's mediating role. Career Development Quarterly, 64(2), 169180.

D'Abate, C.P., Youndt, M.A., \& Wenzel, K.E. (2009). Making the most of an internship: An empirical study of internship satisfaction. Academy of Management Learning and Education, 8(4), 527-539.

Davey, A., \& Tucker, L. (2010). Enhancing higher education students' employability and career management. Library Review, 59(6), 445-454.

De Pillis, E., \& Johnson, G. (2015). First, do no harm: effective, ineffective and counterproductive Teaching Methods. Journal of Higher Education Theory and Practice, 15(1), 58-69. 
Dewey, J. (1933). How we think. Buffalo, NY: Prometheus Books. (Original work published 1910).

Divine, R.L., Linrud, J.K., Miller, R.H., \& Wilson, J.H. (2007). Required internship programs in marketing: Benefits, challenges and determinants of fit. Marketing Education Review, 17(2), 4552.

Ferren, A.S., \& Anderson, C.B. (2016). Integrating learning: Making liberal education purposeful, personal, and practical. New Directions for Teaching and Learning, 145, 33-40.

Ferren, A. S., \& Paris, D. C. (2015). Faculty Leadership for Integrative Liberal Learning. Washington, DC: Association of American Colleges and Universities.

Gault, J., Redinton, J., \& Schlager, T. (2000). Undergraduate business internships and career success: Are they related? Journal of Marketing Education, 22(1), 45-53.

Gault, J., Leach, E., \& Duey, M. (2010). Effects of business internships on marketability: the employer's perspective. Education \& Training, 52(1), 76-88.

Gregg, J., \& Stewart, D.W. (2013). Speculations on the Future of Graduate Management Education. Journal of Higher Education Theory and Practice, 13(2), 11-24.

Hooley, T., Watts, A.G., Sultana, R.G., \& Neary, S. (2013). The blueprint framework for career management skills: A critical exploration. British Journal of Guidance and Counseling, 41(2), 117-131.

Huber, M., \& Hutchings, P. (2004). Integrative learning: mapping the terrain. Association of American Colleges \& Universities (AAC\&U) and The Carnegie Foundation. Retrieved from http://www.carnegiefoundation.org/

Jarvis, P., \& Kelley, E. (2003). From vocational decision making to career building: Blueprint, real games, and school counseling. Ottawa, Ontario: National Life/Works Centre.

Kao, D., \& Mao, T. (2011). A framework for aligning business education with dynamic changes in global competition. Journal of Higher Education Theory and Practice, 11(1), 9-20.

Keishing, V., \& Renukadevi, S. (2016). A review of knowledge management-based career exploration system in engineering education. Journal of Modern Education and Computer Science, 1, 8-15.

Knemeyer, A. M., \& Murphy, P. R. (2001). Logistics internships: Employer perspectives. Transportation Journal, 41(1), 16-26.

Krieshok, T. S., Black, M. D., \& McKay, R. A. (2009). Career decision making: The limitsof rationality and the abundance of non-conscious processes. Journal of Vocational Behavior, 75, 275-290.

Levi, M., \& Ziegler, S. (1993). The role of career exploration as a component of an effective guidance program in the transition. Guidance \& Counseling, 8, 6-15.

MacDermott, C.S. (2017). Mutually beneficial experiences: The 3 Ps to effective internships. The Experience Magazine: Practice and Theory, 88-96.

MacDermott, C., \& Ortiz, L. (2017). Beyond the business communication course: A historical perspective of the where, why, and how of soft skills development and job readiness for business graduates. The IUP Journal of Soft Skills, 11(2), 7-25.

Minton-Eversole, T. (2012). Concerns grow over workforce retirements and skills gap. Retrieved from https://www.shrm.org.resourcesandtools/hr-topics/talent acquisition/pages/workforceretirementandskillsgap.aspx

Ortiz, L., Sebest, M., \& MacDermott, C.S. (March 2016). Employer perceptions of oral competencies most valued in new hires as a factor in company success. Business and Professional Communication Quarterly, 79(3), 317-330.

Pool, L., Qualter, P., \& Sewell, P. (2013). Exploring the factor structure of the career EDGE employability development profile. Journal of Education \& Training, 56(4), 303-313.

Porfeli. E., \& Skorikov, V. (2010). Specific and Diversive Career Exploration During Late Adolescence. Journal of Career Assessment, 18(1), 46-58.

Rodgers, C. (2002). Defining reflection: another look at John Dewey and reflective thinking. Teachers College Record, 104(4), 842-866.

Rover, D. (2007). Integrative Learning. Journal of Engineering Education: The Academic Bookshelf, 275277.

134 Journal of Higher Education Theory and Practice Vol. 18(6) 2018 
Rudgers, L.M., \& Peterson, J.A., (2017). Trends in 2017. Inside Higher Education. Retrieved from https://www.insidehighered.com/views/2017/01/13/upcoming-trends-2017-colleges-shouldprepare-essay\#.WHi80JsVT1U.twitter

Seymour, S., \& Lopez, S. (2015). Big six college experiences linked to life preparedness. Retrieved from http://www.gallup.com/poll/182306/big-six-college-experiences-linked-life-preparedness.aspx

Smith, J. (2014). Internship Wish List: The 12 Things Students Value Most. Retrieved from https://www.forbes.com/sites/jacquelynsmith/2014/01/08/internship-wish-list-the-12-thingsstudents-value-most/\#2b53888d7b2f

Stumpf, S.A., et al. (1983). Development of the career exploration survey (CES). Journal of Vocational Behavior, 22, 191-226.

Stumpf, S.A., et al. (1984). The impact of career exploration and interview readiness on interview performance and outcomes. Journal of Vocational Behavior, 24, 221-235.

Thompson, D. (Aug 19, 2014). The thing employers look for when hiring recent graduates. The Atlantic, Retrieved from https://www.theatlantic.com/business/archive/2014/08/the-thing-employers-lookfor-when-hiring-recent-graduates/378693/ 


\section{APPENDIX A}

\section{SUPERVISOR'S FINAL INTERN EVALUATION SURVEY}

This form is provided to help you assess your intern at the end of the term. This evaluation also provides the student with documentation of his/her experience with your organization. In addition, it aids the faculty in identifying areas where we can be more effective in helping our students acquire the necessary skills and abilities needed in your industry. If you have any questions, please Contact ---- at --- or by email.

*Organization Name: (1)

*Your Name: (2)

*Phone Number: (3)

*Email Address: (4)

*Intern's Name: (5)

Q22 Please evaluate your Intern. Use the following scale:
Unacceptable
Exceptional
$\begin{array}{lllllllllll}0 & 10 & 20 & 30 & 40 & 50 & 60 & 70 & 80 & 90 & 100\end{array}$ 


\begin{tabular}{|c|c|}
\hline Computer Skills () & 且 \\
\hline \multicolumn{2}{|l|}{ Organizational Skills () } \\
\hline \multicolumn{2}{|l|}{ Punctuality () } \\
\hline \multicolumn{2}{|l|}{ Dependability () } \\
\hline \multicolumn{2}{|l|}{ Professionalism () } \\
\hline \multicolumn{2}{|l|}{ Flexibility () } \\
\hline \multicolumn{2}{|l|}{ Self Starter () } \\
\hline \multicolumn{2}{|l|}{ Effort () } \\
\hline \multicolumn{2}{|l|}{ Accountable for Actions () } \\
\hline \multicolumn{2}{|l|}{ Ethical Behavior () } \\
\hline \multicolumn{2}{|l|}{ Written Communication () } \\
\hline \multicolumn{2}{|l|}{ Oral Communication () } \\
\hline \multicolumn{2}{|l|}{ Interpersonal skills () } \\
\hline \multicolumn{2}{|l|}{ Productivity () } \\
\hline \multicolumn{2}{|l|}{ Quality of Work () } \\
\hline \multicolumn{2}{|l|}{$\begin{array}{r}\text { Other Areas of Performance specific to this Internship } \\
\text { (Please identify area and then score) Area: }()\end{array}$} \\
\hline \multicolumn{2}{|l|}{ Area ()} \\
\hline Intern's Overall Performance () & 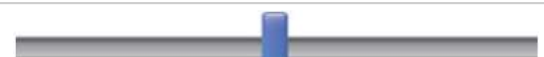 \\
\hline
\end{tabular}


Q11 I would recommend this student for another internship or job.

without hesitation (1)

with reservations (2)

I would not recommend (3)

\section{Q12 Comments}

Q15 Please comment on the overall performance of your intern.

Q16 As a supervisor, do you have any comments about our Business Internship Program?

Q23 May we quote you (only from comments made in the question above) on our website or in other university publications?

Yes, can use my name (1)

Yes, can use my company name (2)

Yes, but please do not use either my name or company name (3)

No, I'd prefer these comments be reserved for only the faculty member's review. (4)

Q25

How useful was the
beginning of the semester
letter from the faculty in
clarifying your role as an
internship site supervisor?

How useful was the midterm correspondence from the faculty in assisting you

with your role as an internship site supervisor?

(2)

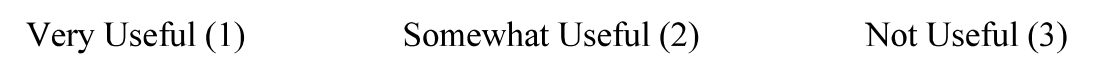


Q26 What other information would have been helpful to you during the internship program?

Q17 Would you be willing to accept another intern?

Yes (1)

No (2)

Q18 If so, how may we contact you?

Q24 Thank you for the mentorship, guidance, and opportunities provided to our Intern. 


\section{APPENDIX B}

SUMMARY OF RESULTS FROM SUPERVISOR INTERN EVALUATION

\begin{tabular}{|c|c|c|c|c|c|c|c|}
\hline$\#$ & Field & Minimum & Maximum & Mean & $\begin{array}{r}\text { Std } \\
\text { Deviation }\end{array}$ & Variance & Count \\
\hline 1 & Computer Skills & 34.00 & 100.00 & 93.96 & 9.43 & 88.84 & 141 \\
\hline 2 & Organizational Skills & 32.00 & 100.00 & 93.55 & 8.93 & 79.79 & 143 \\
\hline 3 & Punctuality & 44.00 & 100.00 & 95.20 & 8.12 & 65.89 & 143 \\
\hline 4 & Dependability & 54.00 & 100.00 & 95.90 & 7.15 & 51.13 & 143 \\
\hline 5 & Professionalism & 66.00 & 100.00 & 95.85 & 6.89 & 47.41 & 143 \\
\hline 6 & Flexibility & 52.00 & 100.00 & 95.78 & 7.73 & 59.82 & 138 \\
\hline 7 & Self-Starter & 41.00 & 100.00 & 94.36 & 8.78 & 77.02 & 140 \\
\hline 8 & Effort & 29.00 & 100.00 & 96.06 & 8.59 & 73.84 & 143 \\
\hline 9 & Accountable for Actions & 49.00 & 100.00 & 96.43 & 6.78 & 45.92 & 142 \\
\hline 10 & Ethical Behavior & 61.00 & 100.00 & 98.06 & 5.26 & 27.68 & 142 \\
\hline 11 & Written Communication & 61.00 & 100.00 & 94.50 & 6.98 & 48.71 & 131 \\
\hline 12 & Oral Communication & 47.00 & 100.00 & 95.30 & 7.12 & 50.65 & 141 \\
\hline 13 & Interpersonal skills & 71.00 & 100.00 & 96.44 & 5.77 & 33.29 & 142 \\
\hline 14 & Productivity & 65.00 & 100.00 & 96.18 & 6.01 & 36.15 & 142 \\
\hline 15 & Quality of Work & 25.00 & 100.00 & 95.97 & 7.94 & 63.05 & 143 \\
\hline 16 & $\begin{array}{r}\text { Other Areas of Performance } \\
\text { specific to this Internship (Please } \\
\text { identify area and then score) } \\
\text { Area: }\end{array}$ & 0.00 & 100.00 & 89.95 & 25.01 & 625.65 & 60 \\
\hline 17 & Area & 0.00 & 100.00 & 92.25 & 18.98 & 360.40 & 28 \\
\hline 18 & Intern's Overall Performance & 0.00 & 100.00 & 96.04 & 9.72 & 94.50 & 133 \\
\hline
\end{tabular}




\begin{tabular}{|c|c|c|c|c|c|c|c|}
\hline$\#$ & Field & Minimum & Maximum & Mean & $\begin{array}{r}\text { Std } \\
\text { Deviation }\end{array}$ & Variance & Count \\
\hline 1 & Computer Skills & 70.00 & 100.00 & 86.60 & 10.95 & 119.84 & 10 \\
\hline 2 & Organizational Skills & 50.00 & 100.00 & 77.90 & 15.45 & 238.69 & 10 \\
\hline 3 & Punctuality & 0.00 & 100.00 & 59.30 & 35.07 & 1230.01 & 10 \\
\hline 4 & Dependability & 20.00 & 90.00 & 70.20 & 21.38 & 456.96 & 10 \\
\hline 5 & Professionalism & 54.00 & 90.00 & 75.90 & 11.09 & 123.09 & 10 \\
\hline 6 & Flexibility & 54.00 & 100.00 & 80.70 & 14.20 & 201.61 & 10 \\
\hline 7 & Self-Starter & 25.00 & 92.00 & 72.60 & 18.77 & 352.44 & 10 \\
\hline 8 & Effort & 55.00 & 100.00 & 78.10 & 13.79 & 190.29 & 10 \\
\hline 9 & Accountable for Actions & 12.00 & 100.00 & 75.40 & 22.91 & 524.84 & 10 \\
\hline 10 & Ethical Behavior & 70.00 & 100.00 & 86.10 & 11.15 & 124.29 & 10 \\
\hline 11 & Written Communication & 80.00 & 100.00 & 85.44 & 7.44 & 55.36 & 9 \\
\hline 12 & Oral Communication & 59.00 & 100.00 & 78.80 & 11.58 & 134.16 & 10 \\
\hline 13 & Interpersonal skills & 31.00 & 100.00 & 80.00 & 18.72 & 350.40 & 10 \\
\hline 14 & Productivity & 63.00 & 88.00 & 77.00 & 7.60 & 57.80 & 10 \\
\hline 15 & Quality of Work & 70.00 & 96.00 & 81.30 & 8.33 & 69.41 & 10 \\
\hline 16 & $\begin{array}{r}\text { Other Areas of Performance } \\
\text { specific to this Internship (Please } \\
\text { identify area and then score) } \\
\text { Area: }\end{array}$ & 23.00 & 100.00 & 74.60 & 27.03 & 730.64 & 5 \\
\hline 17 & Area & 24.00 & 95.00 & 63.00 & 29.41 & 864.67 & 3 \\
\hline 18 & Intern's Overall Performance & 70.00 & 85.00 & 77.50 & 5.64 & 31.85 & 10 \\
\hline
\end{tabular}




\begin{tabular}{|c|c|c|c|c|c|c|c|}
\hline \# & Field & Minimum & Maximum & Mean & $\begin{array}{r}\text { Std } \\
\text { Deviation }\end{array}$ & Variance & Count \\
\hline 1 & Computer Skills & 81.00 & 91.00 & 86.00 & 5.00 & 25.00 & 2 \\
\hline 2 & Organizational Skills & 78.00 & 90.00 & 84.00 & 6.00 & 36.00 & 2 \\
\hline 3 & Punctuality & 49.00 & 90.00 & 69.50 & 20.50 & 420.25 & 2 \\
\hline 4 & Dependability & 20.00 & 97.00 & 58.50 & 38.50 & 1482.25 & 2 \\
\hline 5 & Professionalism & 20.00 & 95.00 & 57.50 & 37.50 & 1406.25 & 2 \\
\hline 6 & Flexibility & 81.00 & 98.00 & 89.50 & 8.50 & 72.25 & 2 \\
\hline 7 & Self-Starter & 29.00 & 94.00 & 61.50 & 32.50 & 1056.25 & 2 \\
\hline 8 & Effort & 40.00 & 97.00 & 68.50 & 28.50 & 812.25 & 2 \\
\hline 9 & Accountable for Actions & 30.00 & 95.00 & 62.50 & 32.50 & 1056.25 & 2 \\
\hline 10 & Ethical Behavior & 70.00 & 96.00 & 83.00 & 13.00 & 169.00 & 2 \\
\hline 11 & Written Communication & 42.00 & 91.00 & 66.50 & 24.50 & 600.25 & 2 \\
\hline 12 & Oral Communication & 42.00 & 90.00 & 66.00 & 24.00 & 576.00 & 2 \\
\hline 13 & Interpersonal skills & 40.00 & 97.00 & 68.50 & 28.50 & 812.25 & 2 \\
\hline 14 & Productivity & 39.00 & 98.00 & 68.50 & 29.50 & 870.25 & 2 \\
\hline 15 & Quality of Work & 40.00 & 96.00 & 68.00 & 28.00 & 784.00 & 2 \\
\hline 16 & $\begin{array}{r}\text { Other Areas of Performance } \\
\text { specific to this Internship (Please } \\
\text { identify area and then score) } \\
\text { Area: }\end{array}$ & 0.00 & 0.00 & 0.00 & 0.00 & 0.00 & 0 \\
\hline 17 & Area & 0.00 & 0.00 & 0.00 & 0.00 & 0.00 & 0 \\
\hline 18 & Intern's Overall Performance & 39.00 & 39.00 & 39.00 & 0.00 & 0.00 & 1 \\
\hline
\end{tabular}

